\title{
Origins and pathways of deeply derived carbon and fluids observed in hot spring waters from non-active volcanic fields, western Kumamoto, Japan
}

\author{
Takahiro Hosono ${ }^{1,2^{*}}$ (D) and Chikashige Yamanaka ${ }^{3}$
}

\begin{abstract}
Natural springs containing volcanic and magmatic components occur in association with these activities. However, features of deeply originated fluids and solutes were less documented from fields, where active volcanic and magmatic activities are not distributed. To characterize the presence of deep components and identify their major pathways 28 groundwater samples ( $1230 \mathrm{~m}$ deep) were collected from hot spring sites located at western coast of Kumamoto, southwestern Japan, where the typical subduction related magmatisms are absent. The samples were measured for dissolved ion concentrations and stable isotope ratios $\left(\delta^{2} \mathrm{H}_{\mathrm{H} 2 \mathrm{O}}, \delta^{18} \mathrm{O}_{\mathrm{H} 2 \mathrm{O}}, \delta^{13} \mathrm{C}_{\mathrm{DIC}}\right.$ and $\left.\delta^{34} \mathrm{~S}_{\mathrm{SO} 4}\right)$ that were compared with data of 33 water samples from vicinity surface systems. The groundwaters were classified into three types based on major hydrochemistry: high $\mathrm{Cl}^{-}$fluid, low concentration fluid, and high $\mathrm{HCO}_{3}{ }^{-}$fluid. Our data set suggests that the high $\mathrm{Cl}^{-}$fluid was formed by saline water mixing with aquifer waters of meteoric origin and subsequently evolved by reverse cation exchange. The low concentration fluid is identical to regional aquifer water of meteoric origin that was subjected to cation exchange. The high $\mathrm{HCO}_{3}{ }^{-}$fluid showed the highest $\mathrm{HCO}_{3}{ }^{-}$concentrations $(\sim 3,888 \mathrm{mg} / \mathrm{l})$ with the highest $\delta^{13} \mathrm{C}_{\mathrm{DIC}}$ (up to $-1.9 \%$ ). Based on our carbon mixing model and observed $\delta^{2} \mathrm{H}_{\mathrm{H} 2 \mathrm{O}}$ and $\delta^{18} \mathrm{O}_{\mathrm{H} 2 \mathrm{O}}$ shifts, it is suggested that dissolved carbon of mantle origin and small fraction of fluids generated in deep crust were transported towards surface through structural weakness under open tectonic setting. These deeply derived components were then mixed with waters in the surface systems and diluted. Their impacts on surface hydrological systems were limited in space except few locations, where deeply connected pathways are anticipated along active structural deformations.
\end{abstract}

Keywords: Mantle, Crust, Fault, Groundwater, Hot spring, Carbon isotope

\section{Introduction}

Artesian springs with high temperature and/or elevated concentrations occur in major active volcanic and seismotectonic regions globally. These highly concentrated dissolved solutes are facilitated with incorporation of volcanic and magmatic gases and fluids (Aiuppa et al.

\footnotetext{
*Correspondence: hosono@kumamoto-u.ac.jp

${ }^{1}$ Faculty of Advanced Science and Technology, Kumamoto University,

2-39-1 Kurokami, Kumamoto 860-8555, Japan

Full list of author information is available at the end of the article
}

2009, 2017), and simultaneous high temperature weathering or alterations that can occur in crust deeper than active hydrological systems in surface (Hedenquist and Lowenstern 1994). Discharge of these fluids is commonly observed in vicinity of active volcano-hydrothermal fields. For example, relevant number of studies tried to depict origins and pathways of deeply sourced components to quantify the impact of volcanic and magmatic activities on lateral material transportations from land to ocean (Chiodini et al. 2000; Dessert et al. 2009; Gaillardet et al. 2011; Rive et al. 2013; Hosono et al. 2018; 
Perez-Fodich and Derry 2019). Similar high concentration hot spring waters are found in regions, where active volcanic and magmatic activities are not existing (Tomaru et al. 2007; Kusuda et al. 2014; Togo et al. 2014; Morikawa et al. 2016; Kusuhara et al. 2020 and references therein). However, origin, distribution, pathway, and thus their impact of hydrochemical features on surface systems are less well known for these waters.

The major sources invoked to explain for the origin of deeply originated fluids include magmatic fluids, slab fluids and deep crustal fluids (Hedenquist and Lowenstern 1994; Ague 2014; Morikawa et al. 2016). The magmatic fluids present in a crust beneath active volcanoes that are located typically along the volcanic front with some possible exceptions on back arc. Dehydration of subducting oceanic plates releases waters and fluids from slab sediments and rocks (here we call slab fluids) into mantle wedges. Some many hot springs in southwest Japan are thought to be originated directly of these fluids on fore arc system (Tomaru et al. 2007; Kusuda et al. 2014; Togo et al. 2014; Yoshida et al. 2015; Morikawa et al. 2016; Kusuhara et al. 2020). Alternatively, fluids generated in lower crust (here we call deep crustal fluids) can also contribute to surface systems along major pathways especially at regions, where substantial heat source exists beneath lower crust, such as upwelling asthenospheric mantle (e.g., Zhao et al. 2018); however, this phenomenon has been less advocated from nature of lived hot spring discharges due to rare opportunity to test this hypothesis.

Previous studies (Nakajima and Hasegawa 2007; Hirose et al. 2008; Zhao et al. 2021) showed the depth contours of subducting slabs under Japanese archipelago demonstrating that western Kyushu is located on unique setting, where possible subduction plate is in mantle deeper than $200 \mathrm{~km}$ and typical subduction related magmatisms are absent. Some hot springs occur along the coast of western Kumamoto in western Kyushu without linkage of active volcanisms in surface (Fig. 1a). Notably, these historically recognized hot springs and other recently developed hot spring facilities are located along and on extension of the major faults (Fig. 1) that possibly allow deeply originated gases and fluids in the crust passing toward surface. There have been no reports comprehensively investigating the origin and formation of these hot springs; however, we thought that precise geochemical characterization on these hot springs may be able to put more constraint on a presence, properties, and discharging processes of these components.

Stable isotopes are useful for identifying the origin of waters and dissolved ions, and for interpreting the biogeochemical processes in aquifers (Kendall 1998; Cook and Herczeg 2000). Stable isotope ratios of oxygen and hydrogen in water molecule $\left(\delta^{2} \mathrm{H}\right.$ and $\left.\delta^{18} \mathrm{O}\right)$ have been used to examine the contribution of fluids that had experienced high temperature water-rock interaction resulting in $\delta^{18} \mathrm{O}$ isotopic shift towards enriched compositions leaving $\delta^{2} \mathrm{H}$ unchanged (Giggenbach 1992). Stable carbon isotope ratio of dissolved inorganic carbon $\left(\delta^{13} \mathrm{C}\right)$ is a fundamental tracer for identifying a contribution of magmatic or mantle derived carbon in fluids (e.g., Chiodini et al. 2000; Yamada et al. 2011; Rive et al. 2013). Sulfur isotope ratio of dissolved sulfate $\left(\delta^{34} S\right)$ is also applicable for evaluating volcanic influence on spring waters and for interpreting redox processes in aquifer environments (e.g., Kusakabe et al. 2000; Hosono et al. 2014a, 2018). This study integrates the results from these isotopic analyses and characterized geochemical features of hot spring waters with comparison of those from other surface waters for trying to reveal the upwelling signatures of deeply originated components in crust and to assess their impact on surface hydrological systems.

\section{Outline of the study area}

The study area is located on the western coast of the Kumamoto Prefecture in Kyushu Islands and consists of four local domains, Uto, Amakusa, Yatsushiro and Ashikita districts (Fig. 1b). Uto and Amakusa are located on western peninsula and small islands, while Yatsushiro and Ashikita are on western coast of the main island Kyushu, respectively. Coastal flat plain in Yatsushiro is the reclaimed land on tidal flat. The Kyushu has humid subtropical climate and average annual temperature and precipitation of Amakusa and Yatsushiro are 16.4 and $16.8^{\circ} \mathrm{C}$ and 2,076 and 1,979 mm during 1981-2010, respectively (http://www.jma.go.jp/jma/menu/report. $\mathrm{html}$ ). Around $40 \%$ of total precipitation occurs during summer rainy season in June and July.

In the Kyushu Islands the active volcanoes are generally situated in two major graben structures, BeppuShimabara and Kagoshima grabens (Fig. 1a) (Nakada et al. 2016) that are facilitated by a unique open tectonic setting partly associated with wet upwelling flow in the mantle wedge (Zhao et al. 2021). The study area is located outside of these graben structures, lying between two major active fault systems, Hinagu and Futagawa strikeslip faults (Fig. 1b), for example, which activities generated the $2016 \mathrm{M}_{\mathrm{w}} 7.0$ Kumamoto destructive earthquakes (e.g., Hosono et al. 2019, 2020). As stated earlier, neither active volcanic activities nor typical subduction related magmatisms are recognized within and beneath the study area. For instance, low frequency micro earthquakes generally occur beneath active volcanoes such as Aso, Kuju and Tsurumi somehow accompanied with low seismic velocity anomalies in the crust, while there is no significant evidence of major magmas or melts anticipated in the crust beneath the study area (Fig. 1c). In contrast, 


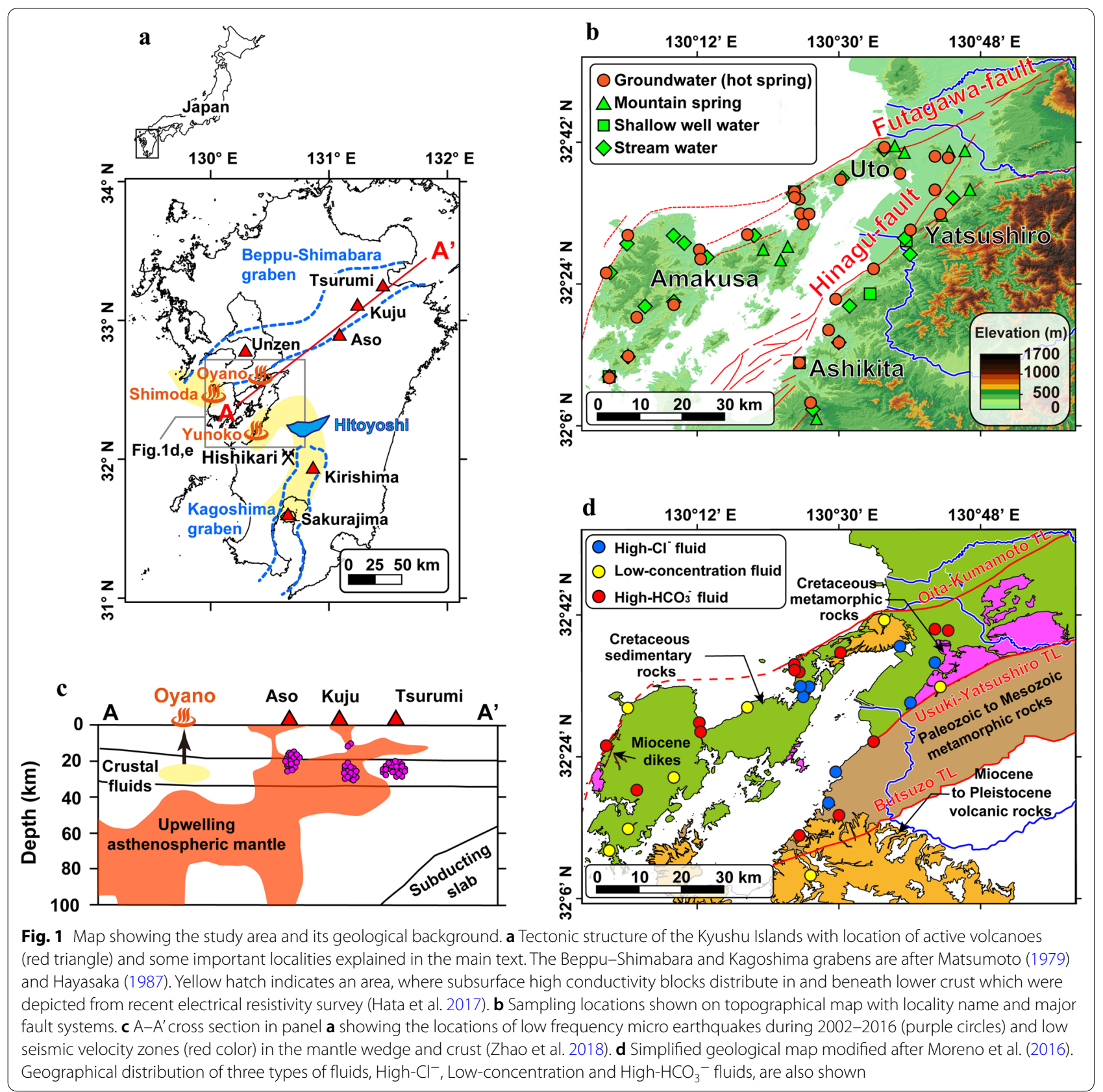

some recent tomography images (Zhao et al. 2018, 2021) depicted the presence of upwelling asthenospheric mantle in the corner of mantle wedge beneath crust under the study area.

Paleozoic to Mesozoic low-temperature and high-pressure metamorphic rocks and metasedimentary rocks of accretionary prism are widely distributed in the southern part of the Usuki-Yatsushiro Tectonic Line (Fig. 1d). In the northern part of this tectonic line Cretaceous Himenoura Group, alternative sedimentary layers of sandstone, mudstone, shale and conglomerate, comprises of the basement rocks of the study area. Cretaceous metamorphic rocks are also outcropped in Amakusa but their distributions are quite limited. These geological basements are overline by Paleogene sedimentary formations which are further intruded by Miocene dikes and overline by Miocene to Pleistocene volcanic rocks mainly of andesitic to dacitic compositions. Most of these young volcanic rocks are found at Uto peninsula (1.7 to 4.2 Ma; Yokose et al. 2009) and Ashikita district (Fig. 1d). Some 
limestone formations are interlayered but their distribution is quite limited that are not seen near majority hot spring sites.

\section{Samples and methods}

In total 28 groundwater samples were collected from borehole of the hot spring facilities except one sample that was collected from artesian spring during June 2019 and May 2020 (Fig. 1b, Additional file 1: Table S1). The depth of borehole is ranging from 70 to $1,230 \mathrm{~m}$ and are generally deeper than $800 \mathrm{~m}$ and temperature of the waters were ranging from 19.8 to $45.2{ }^{\circ} \mathrm{C}$ (Additional file 1: Table S1). Shallow boreholes (70-100 m) are of Yunoko and Shimoda hot springs, which hot springs with Oyano hot spring were first discovered as artesian flowing from the ground (Fig. 1a) and then later explored subsurface by drilling. Other facilities explored groundwater with elevated temperature though originally there were no hot spring discharge symptoms on a surface land. In addition, 19 stream waters, 10 mountain spring waters, and 4 shallow well ( $45 \mathrm{~m}$ in depth) waters were collected within the same area during July 2019 and April 2020 for isotopic and geochemical comparisons (Fig. 1b), which samples are representative for waters in meteologically driven surface hydrological systems (we termed 'surface water' for all these waters). No precipitation occurred during 3 days before the sampling.

Groundwaters from hot spring sites were collected directly from the pipes of the pumping or artesian flows. Stream and artesian mountain spring waters were collected on sites, while shallow well waters were obtained using electric pumping or Baylor tube sampler. Field parameters such as temperature, electrical conductivity, $\mathrm{pH}$, oxidation reduction potential, and dissolved oxygen were monitored using field meters (HORIBA D-54) and water samples were collected after these values became constant. The $\mathrm{HCO}_{3}{ }^{-}$concentration was determined by in situ alkalinity measurement following titrating with sulfuric acid. Water samples were stored in 100, 500 and 2,000 $\mathrm{ml}$ polyethylene bottles for major ion concentrations $\left(\mathrm{Na}^{+}, \mathrm{K}^{+}, \mathrm{Ca}^{2+}, \mathrm{Mg}^{2+}, \mathrm{Cl}^{-}, \mathrm{SO}_{4}{ }^{2-}\right.$, and $\mathrm{NO}_{3}{ }^{-}$), $\delta^{13} \mathrm{C}$ and $\delta^{34} \mathrm{~S}$ analyses, while $20 \mathrm{ml}$ glass vials were used for collecting water samples for $\delta^{2} \mathrm{H}$ and $\delta^{18} \mathrm{O}$ analyses, respectively. The samples were filtered through ADVANTEC $0.2 \mu \mathrm{m}$ cellulose-acetate filters onsite before storing for $100 \mathrm{ml}$ bottles and immediately after taking back to laboratory for 500 and 2,000 $\mathrm{ml}$ bottles, respectively. The filtered water samples in latter two bottles were adjusted to $\mathrm{pH} 12$ to 12.5 with $\mathrm{NaOH}$ and to $\mathrm{pH} 2.5$ to 3 with $6 \mathrm{M}$ $\mathrm{HCl}$, respectively, then dissolved inorganic carbon and $\mathrm{SO}_{4}{ }^{2-}$ were collected as $\mathrm{BaCO}_{3}$ and $\mathrm{BaSO}_{4}$ by adding $10 \% \mathrm{BaCl}_{2}$ for $\delta^{34} \mathrm{~S}$ and $\delta^{13} \mathrm{C}$ analyses.
Major ion concentrations were measured by ion chromatography (Compact IC 761, Metrohm, Switzerland). Both $\delta^{13} \mathrm{C}$ of $\mathrm{BaCO}_{3}$ and $\delta^{34} \mathrm{~S}$ of $\mathrm{BaSO}_{4}$ were determined using a continuous-flow gas ratio mass spectrometer (Delta V Advantage, Thermo Fisher Scientific, USA) interfaced with an elemental analyzer (Thermo Fisher Flash 2000, USA) (Hosono et al. 2014a, 2015). International standards (NBS123 and OGS-1) and several carbonate and sulfate materials were used for quality check of the measurement data. The precision of both $\delta^{13} \mathrm{C}$ and $\delta^{34} \mathrm{~S}$ analyses were generally better than $\pm 0.2 \%$. The $\delta^{2} \mathrm{H}$ and $\delta^{18} \mathrm{O}$ of water molecular were determined by a gasratio mass spectrometer (Delta $\mathrm{V}$ Advantage, Thermo Fisher Scientific, USA) coupled with an automatic watergas equilibrization devise (Nakano Denshi Co., Ltd., Japan). Based on replicate measurements of standards and samples, the analytical precisions for $\delta^{2} \mathrm{H}$ and $\delta^{18} \mathrm{O}$ were better than $\pm 0.5 \%$ and $\pm 0.05 \%$, respectively.

\section{Results and discussion \\ Hydrochemical classification}

According to trilinear diagram hydrochemical features of groundwater samples from hot spring sites clearly differ from those for surface waters (Fig. 2a). The surface water samples are broadly plotted on compositional field between $\mathrm{Ca}-\mathrm{HCO}_{3}{ }^{-}$type with pristine signature and modern sea water, suggesting presence of sea water mixing into fresh surface waters with lower dissolved solutes (electric conductivity of around $50 \mu \mathrm{S} / \mathrm{cm}$ increased near $1,000 \mu \mathrm{S} / \mathrm{cm}$, Additional file 1: Table S1). On the other hand, the groundwater samples from hot spring sites are exclusively plotted along two different trends with increased concentrations (electric conductivity of $\sim 42,500 \mu \mathrm{S} / \mathrm{cm}$ ), high $\mathrm{Cl}^{-}$with variable $\mathrm{Ca}^{2+}$ ratio and high $\mathrm{Na}^{+}$with variable $\mathrm{HCO}_{3}{ }^{-}$ratio (Fig. 2b). Thus, these groundwaters changed their hydrochemical features owing to several factors including mixing of waters with other origins and geochemical evolutions, such as cation exchange and redox processes.

The groundwater samples categorized by the former trend are relatively more enriched in $\mathrm{Cl}^{-}$and $\mathrm{Na}^{+}$and thus we classified this type of waters as $\mathrm{High}-\mathrm{Cl}^{-}$fluid (Fig. 2b, c, Additional file 1: Table S1). The groundwater samples categorized by the latter trend are subdivided into two groups, one characterized with greater $\mathrm{HCO}_{3}{ }^{-}$concentrations $(\sim 3,888 \mathrm{mg} / \mathrm{l})$ and the other with least dissolved concentrations but with relatively higher $\mathrm{SO}_{4}{ }^{2-}$ ratio (Fig. 2d). We classified these two types of groundwaters and named High- $\mathrm{HCO}_{3}{ }^{-}$fluid and Lowconcentration fluid, respectively (Fig. 2b, d, Additional file 1: Table S1). Geographical distribution of three types of fluids, High-Cl ${ }^{-}$, Low-concentration and High$\mathrm{HCO}_{3}{ }^{-}$fluids, are shown in Fig. 1d. This hydrochemical 

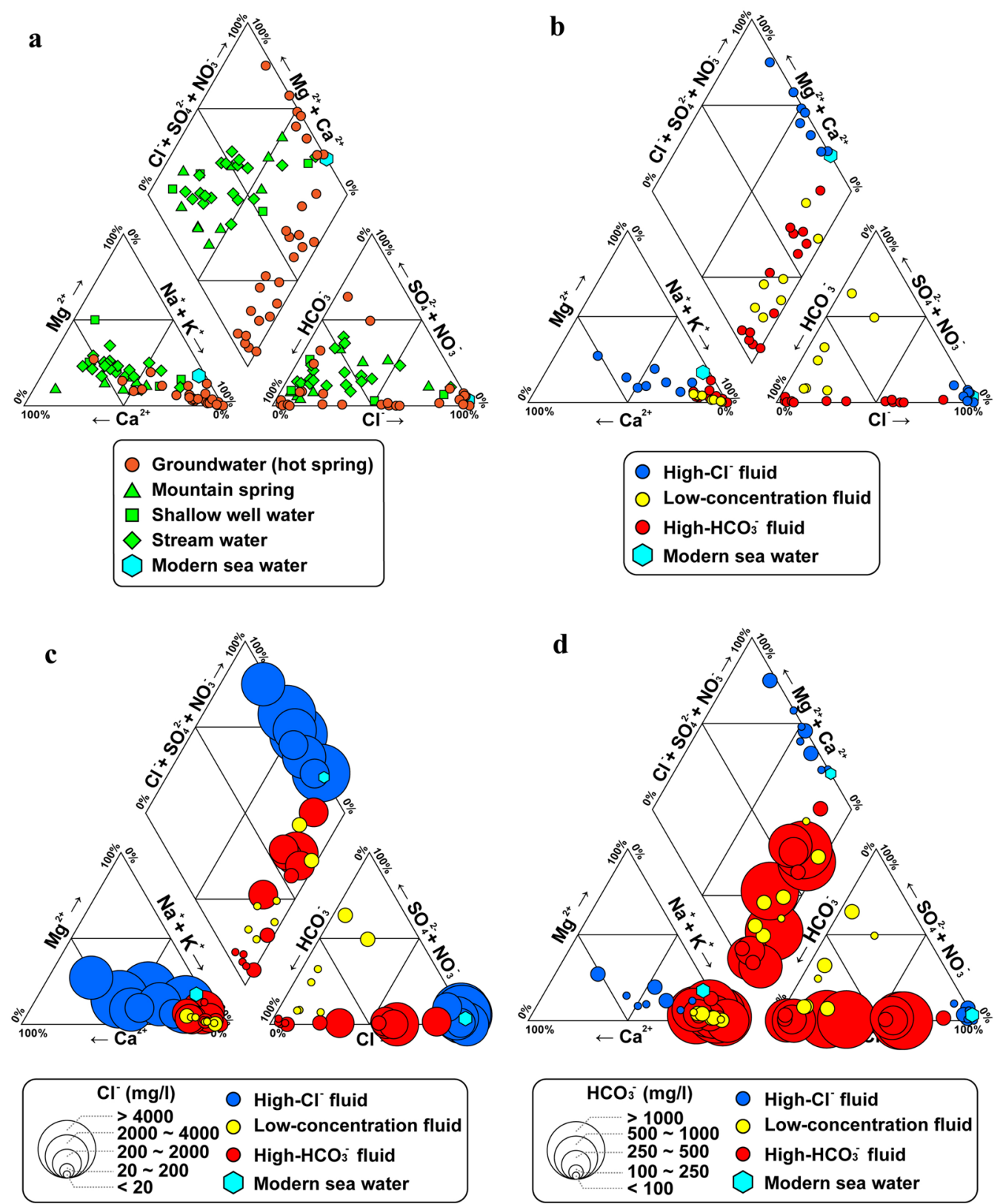

Fig. 2 Hydrochemical classification based on trilinear diagram. a Comparison between surface waters and groundwaters from hot spring sites. b Classification of three different types of groundwaters from hot spring sites. $\mathbf{c}$ Difference in $\mathrm{Cl}^{-}$concentrations among three types of fluids. $\mathbf{d}$ Diversity in $\mathrm{HCO}_{3}{ }^{-}$concentrations among three types of fluids

classification and terminology are used in the following discussion.

\section{Origin of water}

Figure 3 shows $\delta^{2} \mathrm{H}$ versus $\delta^{18} \mathrm{O}$ diagrams plotting all collected samples and data of some hypothesized source waters for comparison. This comparison allows us to identify the possible origins of water samples.
All surface water samples were closely plotted on local meteoric water line except one stream water sample that is slightly deviated towards composition of modern sea water (Fig. 3a). This suggests that all these waters are mainly of meteoric origin except one sample that was clearly affected by a mixing of sea water. We admit that some of these waters are affected by sea water component in terms of major ion chemistry. However, 

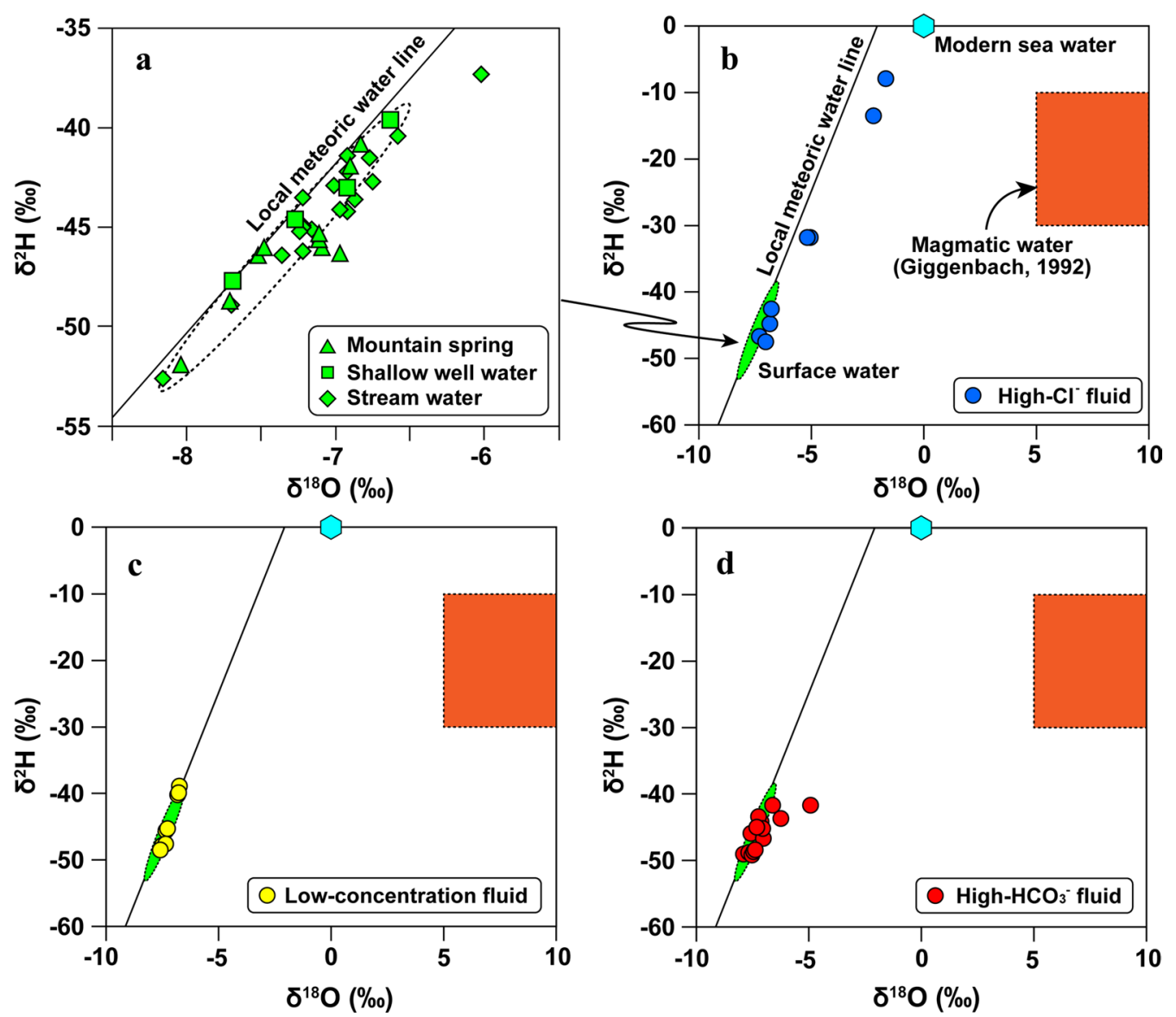

Fig. $3 \delta^{2} \mathrm{H}$ versus $\delta^{18} \mathrm{O}$ diagrams. a-d Isotopic signatures for the surface waters, High-Cl- ${ }^{-}$Low-concentration, and High- $\mathrm{HCO}_{3}{ }^{-}$fluids, respectively. Isotopic compositional field for hypothesized magmatic water is after Giggenbach (1992). Local meteoric water line in Kumamoto (ca. 20 km northeast from Uto district) is after Okumura et al. (2018)

this effect was small and not obviously reflected on $\delta^{2} \mathrm{H}$ and $\delta^{18} \mathrm{O}$ shifts. Thus their compositions were regard as representative feature of waters in surface hydrological systems over the study area.

In Fig. 3b, samples of High- $\mathrm{Cl}^{-}$fluid are broadly plotted along an array between compositional field of surface waters and modern sea water. In combination with $\mathrm{Cl}^{-}$concentration (Additional file 2: Fig. S1), our simple mixing model suggests that this fluid was originated of the surface fresh water admixed with modern sea water with variable mixing proportions ranging from few to nearly $100 \%$ due to sea water intrusion and/or contribution of saline pore waters in sediments. This interpretation agrees well with the fact that all High- $\mathrm{Cl}^{-}$fluids are located just on the coasts or on the reclaimed land in Yatsushiro (Fig. 1d). In turn, for Lowconcentration fluid all sample plots were fallen on the compositional field of the surface water (Fig. 3c), indicating their intrinsic meteoric origin analogous to surface circulated waters.
In contrast to High-Cl ${ }^{-}$and Low-concentration fluids, some samples of High- $\mathrm{HCO}_{3}{ }^{-}$fluid are plotted on right to the local meteoric water line towards hypothesized magmatic water proposed by Giggenbach (1992) (Fig. 3d), although this isotopic shift seems not to be much drastic compared to ones reported from some volcanic fields and other hot spring waters of subduction slab origin (e.g., Kita et al. 2009; Kusuda et al. 2014; Morikawa et al. 2016). Nevertheless, observed isotopic shift possibly indicates incorporation of deep fluids that have experienced high temperature water-rock interaction in deep crust as explained more later.

\section{Geochemical evolution Cation exchange}

High- $\mathrm{Cl}^{-}$fluid showing variable $\mathrm{Ca}^{2+}$ ratio (Fig. 2b) possibly indicates the occurrence of other processes than source inputs, i.e., geochemical evolution. The chloro-alkaline indices (CAI) (Schoeller 1977) expressed by the following equations in milliequivalent 
concentrations can be used to test the occurrence of cation exchange reactions that control cation concentrations in aquifers.

$$
\begin{aligned}
& \mathrm{CAI}-1=\frac{\mathrm{Cl}^{-}-\left(\mathrm{Na}^{+}+\mathrm{K}^{+}\right)}{\mathrm{Cl}^{-}} \\
& \mathrm{CAI}-2=\frac{\mathrm{Cl}^{-}-\left(\mathrm{Na}^{+}+\mathrm{K}^{+}\right)}{\mathrm{SO}_{4}^{2-}+\mathrm{HCO}_{3}^{-}+\mathrm{CO}_{3}^{2-}+\mathrm{NO}_{3}^{-}}
\end{aligned}
$$

Here, the cation exchange and reverse cation exchange are expected to occur when both CAI-1 and CAI-2 show negative and positive values, respectively. The parameter $\mathrm{CO}_{3}{ }^{2-}$ can be neglected when $\mathrm{pH}$ of solutions is lower than 10.3. The $\mathrm{pH}$ measured for our samples were all below 10.3 (Additional file 1: Table S1). Figure 4 displays both CAI-1 and CAI-2 yielded positive values and the values are tended to increase with increase in $\mathrm{Ca}^{2+}$ ratio for the High$\mathrm{Cl}^{-}$fluid. We can thus conclude that hydrochemical features of High- $\mathrm{Cl}^{-}$fluid was formed by the sea component mixing and subsequent progressive reverse cation exchange reaction in aquifer. Exchange of calcium ion in exchangeable site in aquifer's solid phase was released by $\mathrm{Na}^{+}$in water, assuming to easily be enhanced by additives of saline water with high $\mathrm{Na}^{+}$ concentration. Moderately, but similar variation in $\mathrm{Ca}^{2+}$ ratio was observed for Low-concentration and High- $\mathrm{HCO}_{3}{ }^{-}$fluids (Fig. 2). However, both fluids had negative CAI-1 and CAI-2 values which tended to decrease with decrease in $\mathrm{Ca}^{2+}$ ratios (Fig. 4). Thus, these fluids had evolved along normal cation exchange reaction in contrast to $\mathrm{High}-\mathrm{Cl}^{-}$fluid.

\section{Redox process (sulfur cycle)}

The redox process is another important geochemical evolutional process that must be considered. This is true, because some groundwaters from hot spring sites showed low dissolved oxygen $(<2 \mathrm{mg} / \mathrm{l})$ and negative oxidation reduction potential $(\mathrm{mV})$ although surface waters generally showed aerobic regime (Additional file 1: Table S1), implying the occurrence of some anaerobic microbial reductions facilitated in some aquifers. In general, $\mathrm{Cl}^{-}$ concentrations are not affected by redox changes and $\mathrm{NO}_{3}{ }^{-}$was not highly concentrated (mostly $<2.0 \mathrm{mg} / \mathrm{l}$ except three samples with $>10 \mathrm{mg} / \mathrm{l}$ due to local contamination) in the water samples investigated (Additional file 1: Table S1). Thus $\mathrm{Cl}^{-}$and $\mathrm{NO}_{3}{ }^{-}$are not of major interests for the subject to discuss about the issue. Here, additional source characteristics and redox processes will be discussed for $\mathrm{SO}_{4}{ }^{2-}$ with conjunction of $\delta^{34} \mathrm{~S}$ (Fig. 5).

The $\delta^{34} \mathrm{~S}$ and $\mathrm{SO}_{4}{ }^{2-}$ variations for surface waters were considered as juvenile indices that are defined as $-7 \% 0<\delta^{34} \mathrm{~S}<15 \%$ and $2 \mathrm{mg} / \mathrm{l}<\mathrm{SO}_{4}{ }^{2-}<30 \mathrm{mg} / \mathrm{l}$, respectively (Fig. 5a), taking their overall aerobic (Additional file 1: Table S1) and the least contaminated hydrochemical features. In Fig. 5b, some High- $\mathrm{Cl}^{-}$fluids showed elevated $\mathrm{SO}_{4}{ }^{2-}(\sim 1,700 \mathrm{mg} / \mathrm{l})$ towards compositions of modern sea water $\left(\delta^{34} \mathrm{~S}\right.$ : ca. $20.3 \%$, $\mathrm{SO}_{4}{ }^{2-}$ : ca. $2649 \mathrm{mg} / \mathrm{l}$; Rees et al. 1978), suggesting significant saline water contribution as explained previously. However, other samples showed lower concentrations with elevated $\delta^{34} \mathrm{~S}$ up to $28 \%$, indicating an occurrence of microbial reduction of concentrated sulfate of marine origin (Strebel et al. 1990; Tuttle et al. 2009). Some samples were not measured for $\delta^{34} \mathrm{~S}$ because of their low $\mathrm{SO}_{4}{ }^{2-}$ concentrations probably due to progressive sulfate reduction reaction. Such phenomenon is
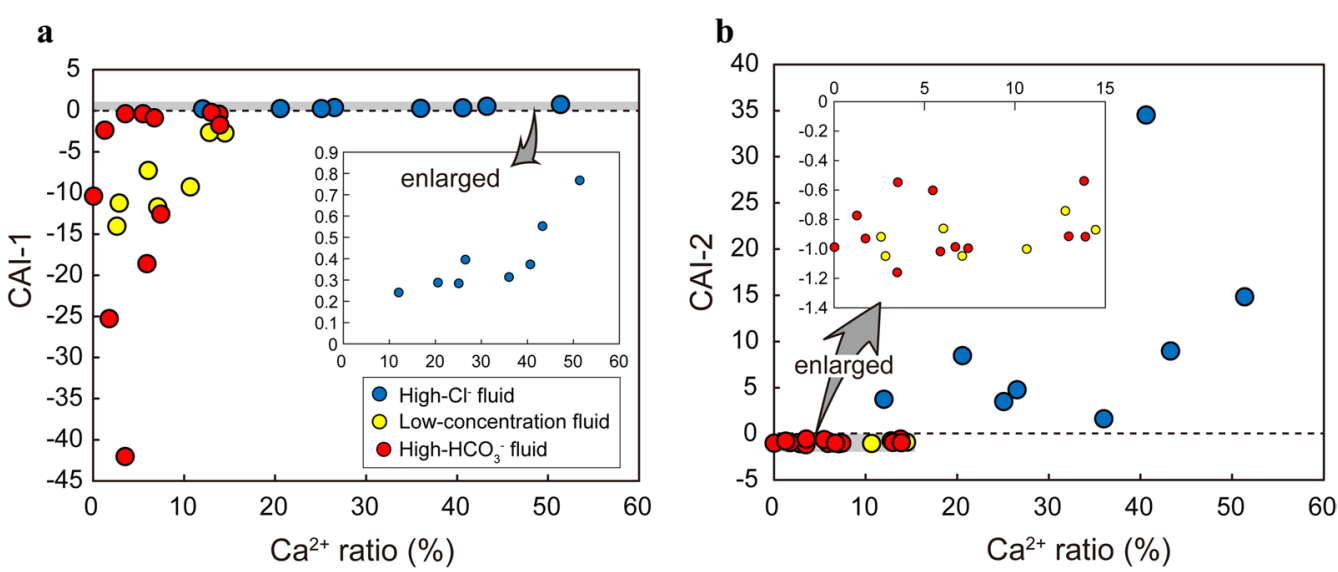

Fig. 4 Biplot diagram between $\mathrm{Ca}^{2+}$ ratio and chloro-alkaline indices. $\mathbf{a}$, b Plot diagrams compare for CAl-1 and CAl-2, respectively, three types of groundwaters from hot spring sites, High-Cl-, Low-concentration, and $\mathrm{High}_{-} \mathrm{HCO}_{3}{ }^{-}$fluids. $\mathrm{Ca}^{2+}$ ratio denotes proportion of calcium ion among four major cations $\left(\mathrm{Na}^{+}, \mathrm{K}^{+}, \mathrm{Ca}^{2+}\right.$ and $\left.\mathrm{Mg}^{2+}\right)$ in milliequivalent concentrations 


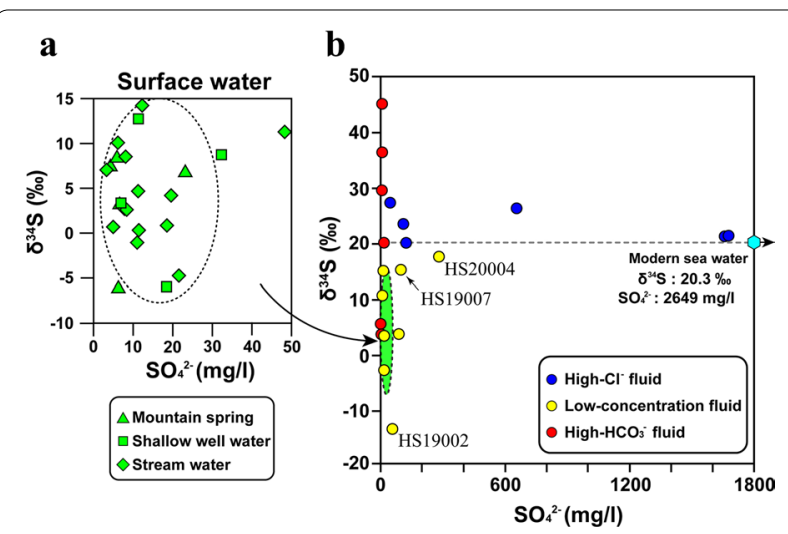

Fig. $5 \mathrm{SO}_{4}{ }^{2-}$ concentration versus $\delta^{34} S$ diagrams. a, b Sample plots for three types of groundwaters from hot spring sites, High- $\mathrm{Cl}^{-}$, Low-concentration, and $\mathrm{High}-\mathrm{HCO}_{3}{ }^{-}$fluids, with comparison of those for surface waters. Compositions of modern sea water are after Rees et al. (1978)

commonly seen for coastal aquifers either at near study fields in Kumamoto (Hosono et al. 2014a) or some other countries (Hosono et al. 2010, 2011, 2014b).

The Low-concentration fluid displayed compositions almost identical to those for surface water except two samples (HS19007 and HS20004) with moderately elevated $\mathrm{SO}_{4}{ }^{2-}(\sim 280 \mathrm{mg} / \mathrm{l})$ and $\delta^{34} \mathrm{~S}(\sim 17.4 \%)$ and one sample (HS19002) with slightly elevated $\mathrm{SO}_{4}{ }^{2-}$ $(57 \mathrm{mg} / \mathrm{l})$ and quite depleted $\delta^{34} \mathrm{~S}(-13.7 \%$ ) (Fig. $5 \mathrm{~b})$. The observed signature for former two samples can be explained by mixing of sulfate of marine origin similar to High- $\mathrm{Cl}^{-}$fluid but that intensity was too small to clearly be detected on stable isotope ratios of water molecular (Fig. 3c). The signature of later sample can be explained by the oxidation of sulfide with lower $\delta^{34} \mathrm{~S}$ (Taylor et al. 1984; van Everdingen and Krouse 1985). In summary, overall hydrochemical formation process of Low-concentration fluid resembles to that for surface waters except cation exchange reaction.

The High- $\mathrm{HCO}_{3}{ }^{-}$fluid has the least $\mathrm{SO}_{4}{ }^{2-}$ concentrations, which are lower than $16 \mathrm{mg} / \mathrm{l}$, and for majority samples, ranging between detection limit and $5 \mathrm{mg} / \mathrm{l}$ (Additional file 1: Table S1). Two samples had similar $\delta^{34} \mathrm{~S}$ compositions to those for surface waters but other four samples showed most enriched $\delta^{34} \mathrm{~S}$ signature ( 45\%) among all samples with depleted $\mathrm{SO}_{4}{ }^{2-}$ concentrations (Fig. 5b). No striking signatures of contribution from marine sulfate are observed, corresponding to results of $\delta^{2} \mathrm{H}$ and $\delta^{18} \mathrm{O}$ analyses. Overall, hydrochemistry of the High- $\mathrm{HCO}_{3}{ }^{-}$fluid was changed their features with similar manner as found for Low-concentration fluid, except least contribution from marine sulfate and tremendous $\mathrm{HCO}_{3}{ }^{-}$enrichment (Fig. 2d).

\section{Upwelling signatures of deeply derived carbon and fluids} Significant contribution of sulfur from some heat sources was not detected from any water samples collected from our study area (Fig. 5), which $\delta^{34} \mathrm{~S}$ values resemble a feature of arc volcanic magmas typically in a range between 0 and $10 \%$ (Ueda and Sakai 1984). On the other hand, elevated $\mathrm{HCO}_{3}{ }^{-}$in $\mathrm{High}-\mathrm{HCO}_{3}{ }^{-}$fluid may be originated of $\mathrm{CO}_{2}$ gas released from some heat sources that was dissolved in waters and preferentially transported towards surface leaving $\mathrm{SO}_{2}$ and other gasses (e.g., Ohsawa et al. 2002; Gultekin et al. 2011). The use of $\delta^{13} \mathrm{C}$ tracer in dissolved inorganic carbon can provide clue to test this hypothesis (Chiodini et al. 2000; Yamada et al. 2011; Rive et al. 2013).

On the $\delta^{13} \mathrm{C}$ versus $\mathrm{HCO}_{3}{ }^{-}$concentration diagram (Fig. 6a), all surface water samples fall on $\delta^{13} \mathrm{C}$ compositions between -31.3 and $-11.8 \%$ with the lowest $\mathrm{HCO}_{3}{ }^{-}$concentrations generally less than ca. $100 \mathrm{mg} / \mathrm{l}$ (Additional file 1: Table S1), except one sample (GW20002) with relatively elevated $\delta^{13} \mathrm{C}(-8.9 \%$ ) and $\mathrm{HCO}_{3}{ }^{-}$concentration $(295 \mathrm{mg} / \mathrm{l})$. These geochemical features are of the typical ecosystem-mediated carbon globally (Clark and Fritz 1997) and aquifer systems near the study areas (Ohsawa et al. 2002; Hosono et al. 2014a) and thus are reasonably assigned as a representative composition of surface water systems before alteration by additional source inputs. On the same diagram, almost all groundwater samples from hot spring sites are plotted along the exponential curved trends based on two end-component mixing models between hypothesized soil $\mathrm{CO}_{2}$ and deep originated $\mathrm{CO}_{2}$, suggesting progressive contribution of $\mathrm{CO}_{2}$ from deep heat source into shallower hydrological systems.

A contribution of deep originated $\mathrm{CO}_{2}$ dominates in High- $\mathrm{HCO}_{3}{ }^{-}$fluid compared to other fluids (High- $\mathrm{Cl}^{-}$ and Low-concentration fluids) which contain only $5 \%$ of carbon from that source (Fig. 6a). Therefore, significant contribution of $\mathrm{CO}_{2}$ from some heat source is responsible for the formation of major hydrochemical features of High- $\mathrm{HCO}_{3}{ }^{-}$fluid. Figure $6 \mathrm{~b}$ displays geographical distribution of relative contribution of carbon from the heat source. It is notable from this map that groundwaters with the greater contributions are sporadically distributed along the fault systems, and interestingly, these anomalies are characteristically located near the historical hot spring sites, i.e., Yunoko, Shimoda and Oyano, regardless of their host geological formations (Fig. 1). It seems plausible, therefore, that the surface geology is not necessarily associated with the occasion of observed deeply sourced carbon, instead, the presence of deeper heat source must be more critically important. The groundwaters with greater $\delta^{2} \mathrm{H}$ and $\delta^{18} \mathrm{O}$ compositional shifts tend to be seen on locations, where deeply 

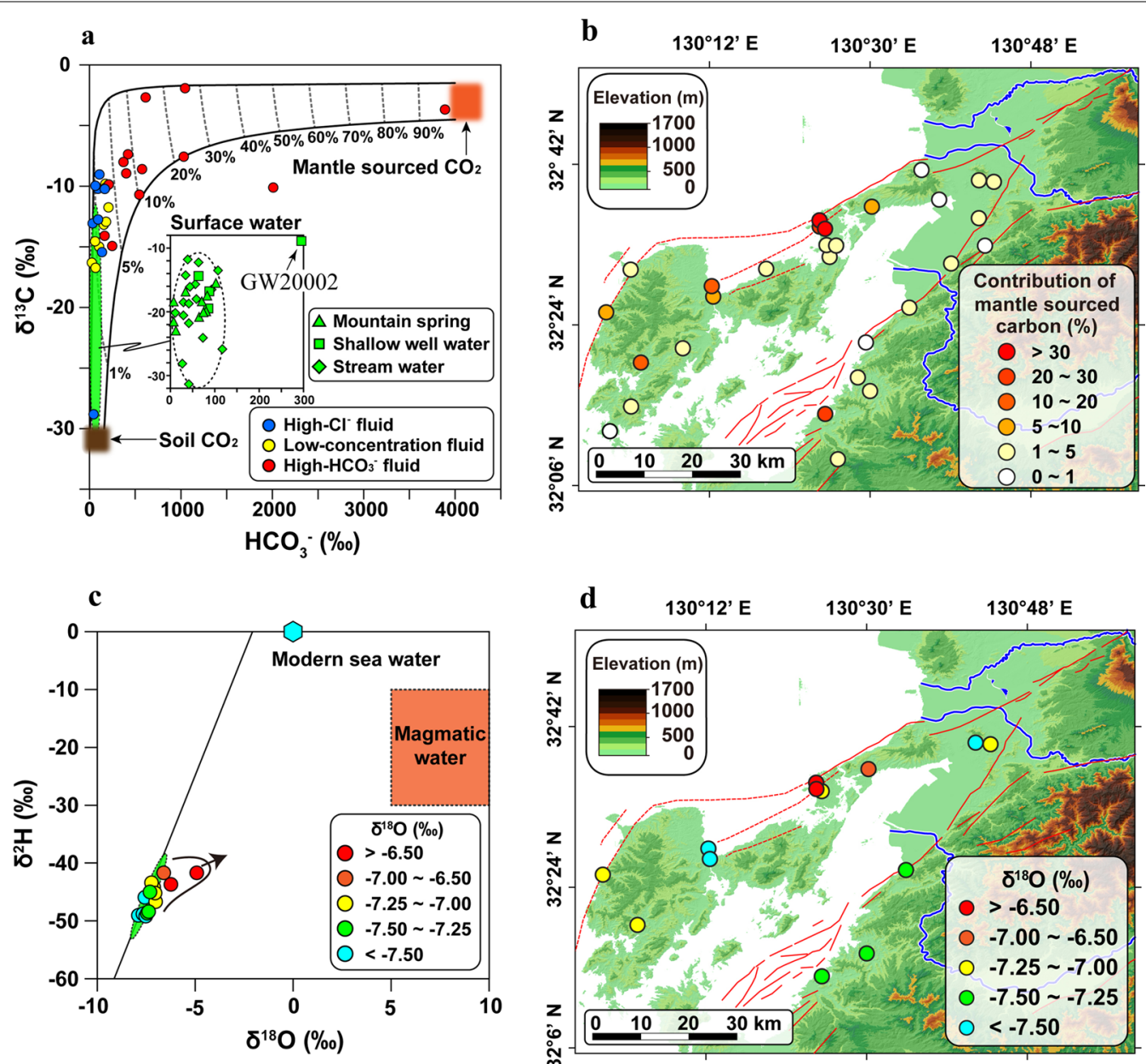

Fig. 6 Identification for deeply originated components. a $\mathrm{HCO}_{3}{ }^{-}$concentration versus $\delta^{13} \mathrm{C}$ diagram for all collected water samples. Simple two components mixing curved lines with relative contribution rates from hypothesized mantle sourced carbon in 10\% interval are shown in the graph. Mixing of two sets of end-components, soil carbon $\left(\mathrm{HCO}_{3}{ }^{-}\right.$and $\delta^{13} \mathrm{C}: 20 \mathrm{mg} / \mathrm{l}$ and $-30 \%$, $160 \mathrm{mg} / \mathrm{l}$ and $-30 \%$, respectively) and mantle sourced carbon $\left(\mathrm{HCO}_{3}{ }^{-}\right.$and $\delta^{13} \mathrm{C}: 4,000 \mathrm{mg} / \mathrm{l}$ and $-4.5 \%$, 4,000 $\mathrm{mg} / \mathrm{l}$ and $-1.5 \%$, respectively) were hypothesized taking compositional variations observed from this study, with a same method applied elsewhere (e.g., Chiodini et al. 2000; Yamada et al. 2011; Rive et al. 2013). b Geographical distribution of relative contribution from mantle sourced carbon in groundwater samples deduced from mixing model shown in panel a. $\mathbf{c} \delta^{2} \mathrm{H}$ versus $\delta^{18} \mathrm{O}$ plot diagram for High- $\mathrm{HCO}_{3}{ }^{-}$fluid shown in different colors with variable $\delta^{18} \mathrm{O}$. d Geographical distribution of $\delta^{18} \mathrm{O}$ values. The symbol color is same as in panel $\mathbf{c}$

originated $\mathrm{CO}_{2}$ occurs (Fig. 6c, d), supporting above scenario.

If there are still lived magmas or melts beneath surface, the observed isotopic features of $\mathrm{High}-\mathrm{HCO}_{3}{ }^{-}$fluid could be explained by involvement of these magmatic gases and fluids; however, the presence of these heat sources has not been reported for particular fields based on scientific evidences. Alternatively, based on well-known geotectonic setting for the study area, upwelling asthenospheric mantle (Zhao et al. 2018, 2021) is the most plausible origin of deeply sourced $\mathrm{CO}_{2}$ that was released into metasomatized lower crust triggered by crustal assimilation with this huge heat source. Similar phenomenon was reported from the Hitoyoshi Basin in non-volcanic field at western Kumamoto (Fig. 1a) based on the same isotopic systematics (Sakai et al. 2011), with some additional noble gas isotopes, e.g., ${ }^{3} \mathrm{He} /{ }^{4} \mathrm{He}$ (Ohsawa et al. 2011).

Hata et al. $(2017,2020)$ provided key information for putting more constraint on the realization of the deep crustal fluids. Their recent electrical resistivity image finely identified significant high conductivity blocks exist in western Kyushu under shallow depth in the upper mantle and lower crust $(\sim 50 \mathrm{~km})$, and argued the presence of deep hydrothermal fluids particularly under Hishikari (hydrothermal gold-silver ore deposits) (Fig. 1a), Hitoyoshi, Ashikita and Amakusa, where deep 
crustal fluid upwelling was anticipated. Thus, we propose fluids generated in a lower crust possibly contributes for the formation of our hypothesized deep fluids, although a possibility of partial involvement of recycled subduction slab fluids can't be neglected as their ultimate origin (Nakamura et al. 2019; Sano and Marty 1994). However, observed degree of isotopic shift on $\delta^{2} \mathrm{H}$ and $\delta^{18} \mathrm{O}$ compositions (Fig. 6c) was not much dramatic as seen for deeply originated $\mathrm{CO}_{2}$ (Fig. 6a) probably due to both dispersion of $\mathrm{CO}_{2}$ gas and mitigation by the mixing with water of meteoric origin, while the deep crustal fluids ascent through long distance in the crust.

Discharging slab originated fluids ubiquitous in southwest Japan is thought to be transported through major tectonic structures, such as Median Tectonic Line, forearc thrust faults in the accretionary prisms and branching faults, driven by geo- and heat pressures under compressional tectonic setting (Kusuda et al. 2014; Togo et al. 2014; Yoshida et al. 2015; Morikawa et al. 2016). Deeply originated gases and fluids proposed in this study could also ascend through structural breaks in the Hinagu and Futagawa strike-slip faulting systems (Fig. 1) and possibly in relation to pressure release under open tectonic setting, with a similar law demonstrated from previous works in Kyushu (Hosono and Nakano, 2004; Hosono et al. 2018) and from other open tectonic regions (e.g., Cerón et al. 1998). It's interesting to note that stronger signature of upwelling of the deeply sourced components (Fig. 6b, d) characteristically occurs near the locations, where more than two different faults are crossing (Fig. 1b). This may be due to generation of lower pressure around cross point of the different stresses in the crust, where pressurized deep fluids can more easily release towards air pressure near surface (Cappa et al. 2009; Takashima and Kano 2005).

The results of this study showed $\delta^{13} \mathrm{C}$ was the most sensible tracers among all measured stable isotope ratios for fingerprinting deeply originated components in groundwaters. It is also useful for identifying the locations of major structural pathways and could be applicable for further investigating deeply connecting fault systems and seismic responses (Barbieri et al. 2020; Barberio et al. 2021; Luccio et al. 2018). Giving that the mantle sourced carbon mediated groundwaters (High- $\mathrm{HCO}_{3}^{-}$fluid) shared nearly half of total analyzed groundwaters (46\%), this type of waters must to be extended wide in space bellow few hundred meters deeper in crust. Despite their prosperity in deep aquifers their discharges to near surface systems look somehow restrictive at, only where major fluid pathways exist, and thus, their overall impacts on surface hydrological systems seem to be small on this particular study setting. In our study area, only minor contamination with mantle originated carbon, i.e., ca. $5 \%$, was observed locally in shallow well water (GW20002, $20 \mathrm{~m}$ in depth) near Yunoko hot spring (Fig. 6a). These aspects can be taken when we consider carbon cycle on earth surface systems in other fields.

\section{Conclusions}

The hydrochemical features of surface and subsurface waters were characterized to understand the origin, distribution and pathway of deeply originated components in hot springs in western Kumamoto using multiple stable isotope ratios $\left(\delta^{2} \mathrm{H}, \delta^{18} \mathrm{O}, \delta^{13} \mathrm{C}\right.$ and $\left.\delta^{34} \mathrm{~S}\right)$ for an area, where subduction-related active volcanic and magmatic activities are not anticipated. Our results implied that dissolved carbon and waters assumed to be originated from upper mantle and lower crust, respectively, could be transported to shallower aquifers along the major pathways. This study illustrates a possible genesis of some carbon rich hot springs appearing on 'back-arc-side' non-volcanic fields. Additional analysis on noble gas isotopes may provide firmer evidence. The aspects from our results are useful for interpreting data from other fields and for more global generalization, and beneficial to users for hot spring resources.

\section{Abbreviations}

MTL: Median Tectonic Line; TL: Tectonic line; DIC: Dissolved inorganic carbon.

\section{Supplementary Information}

The online version contains supplementary material available at https://doi. org/10.1186/s40623-021-01478-1.

Additional file 1: Table S1. Location, property, and measurement and analytical results for all water samples collected in this study from western coast of Kumamoto in western Kyushu, Japan.

Additional file 2: Fig. S1. $\mathrm{Cl}^{-}$concentration versus $\delta^{2} \mathrm{H}$ diagram for High- $\mathrm{Cl}^{-}$fluid. Simple two components (surface water and modern sea water) mixing lines with relative contribution rates from modern sea water in 10\% interval are shown. End-components for surface water with variable compositions $\left(\mathrm{Cl}^{-}\right.$and $\delta^{2} \mathrm{H}: 13.8 \mathrm{mg} / \mathrm{l}$ and $-2.6 \%$ $17.2 \mathrm{mg} / \mathrm{l}$ and - 37.3\%o) were considered.

\section{Acknowledgements}

We thank the hot spring facilities to kindly let us collect water samples for chemical and isotopic analyses. We are grateful for team members of the Kumamoto University for their cordial help during field survey and laboratory analysis.

\section{Authors' contributions}

TH conceived the idea and wrote the manuscript. CY conducted sampling survey and analyzed all data sets. All authors read and approved the final manuscript. 


\section{Funding}

This study was funded by the JSPS Grant-in-Aid for Scientific Research B

(17H01861) and Fostering Joint International Research A (19KK0291).

\section{Availability of data and materials}

All data used in this study are listed in figures and Supplementary Information.

\section{Declarations}

Ethics approval and consent to participate

Not applicable.

\section{Consent for publication}

Not applicable.

\section{Competing interests}

The authors declare no competing interests.

\section{Author details}

${ }^{1}$ Faculty of Advanced Science and Technology, Kumamoto University, 2-39-1 Kurokami, Kumamoto 860-8555, Japan. ${ }^{2}$ International Research Organization for Advanced Science and Technology, Kumamoto University, 2-39-1 Kurokami, Kumamoto 860-8555, Japan. ${ }^{3}$ Department of Earth and Environmental Science, Faculty of Science, Kumamoto University, 2-39-1 Kurokami, Kumamoto 860-8555, Japan.

Received: 24 March 2021 Accepted: 12 July 2021

Published online: 29 July 2021

\section{References}

Ague JJ (2014) Fluid Flow in the Deep Crust. In: Rudnick RL (ed) The Crust. In: Holland HD, Turekian KK (eds) Treatise on Geochemistry, vol 4. Elsevier Science, Second Edition, pp 203-247

Aiuppa A, Baker D, Webster J (2009) Halogens in volcanic systems. Chem Geol 263:1-18

Aiuppa A, Fischer TP, PlankT, Robidoux P, Di Napoli R (2017) Along-arc, inter-arc and arc-to-arc variations in volcanic gas $\mathrm{CO}_{2} / \mathrm{S}_{\mathrm{T}}$ ratios reveal dual source of carbon in arc volcanism. Earth Sci Rev 168:24-47

Barberio MD, Gori F, Barbieri M, Boschetti T, Caracausi A, Cardello GL, Petitta M (2021) Understanding the origin and mixing of deep fluids in shallow aquifers and possible implications for crustal deformation studies: San Vittorino Plain. Central Apennines Appl Sci 11:1353. https://doi.org/10. 3390/app11041353

Barbieri M, Boschetti T, Barberio MD, Billi A, Franchini S, lacumin P, Selmo E, Petitta M (2020) Tracing deep fluid source contribution to groundwater in an active seismic area (central Italy): A combined geothermometric and isotopic $\left(\delta^{13} \mathrm{C}\right)$ perspective. J Hydrol 582:124495. https://doi.org/10. 1016/j.jhydrol.2019.124495

Cappa F, Rutqvist J, Yamamoto K (2009) Modeling crustal deformation and rupture processes related to upwelling of deep $\mathrm{CO}_{2}$-rich fluids during the 1965-1967 Matsushiro earthquake swarm in Japan. J Geophys Res 114:B10304. https://doi.org/10.1029/2009JB006398

Cerón JC, Pulido-Bosch A, Sanz de Galdeano C (1998) Isotopic identification of $\mathrm{CO}_{2}$ from a deep origin in thermomineral waters of southeastern Spain. Chem Geol 149:251-258

Chiodini G, Frondini F, Cardellini C, Parello F, Peruzzi L (2000) Rate of diffuse carbon dioxide Earth degassing estimated from carbon balance of regional aquifers: the case of central Apennine. Italy J Geophys Res Solid Earth 105(B4):8423-8434

Clark ID, Fritz P (1997) Environmental isotopes in hydrogeology. Lewis Publishers, New York

Cook P, Herczeg AL (2000) Environmental Tracers in Subsurface Hydrology. Kluwer Academic Publishers, USA

Dessert C, Gaillardet J, Dupre B, Schott J, Pokrovsky OS (2009) Fluxes of highversus low-temperature water-rock interactions in aerial volcanic areas: example from the Kamchatka Peninsula, Russia. Geochim Cosmochim Acta 73:148-169
Gaillardet J, Rad S, Rive K, Louvat P, Gorge C, Allègre CJ, Lajeunesse E (2011) Orography-driven chemical denudation in the Lesser Antilles: evidence for a new feed-back mechanism stabilizing atmospheric $\mathrm{CO}_{2}$. Am J Sci 311:851-894

Giggenbach WF (1992) Isotopic shifts in waters from geothermal and volcanic systems along convergent plate boundaries and their origin. Earth Planet Sci Lett 113:495-510

Gultekin F, Hatipoglu E, Ersoy AF (2011) Hydrogeochemistry, environmental isotopes and the origin of the Hamamayagi-Ladik thermal spring (Samsun, Turkey). Env Earth Sci 62:1351-1360

Hata M, Uyeshima M, Handa S, Shimoizumi M, Tanaka Y, Hashimoto T, Kagiyama T, Utada H, Munekane H, Ichiki M, Fuji-ta K (2017) 3-D electrical resistivity structure based on geomagnetic transfer functions exploring the features of arc magmatism beneath Kyushu, Southwest Japan Arc. J Geophys Res Solid Earth 122:172-190. https://doi.org/10.1002/2016J B013179

Hata M, Munekane H, Utada H, Kagiyama T (2020) Three-dimensional electrical resistivity structure beneath a volcanically and seismically active island, Kyushu, Southwest Japan Arc. J Geophys Res Solid Earth. https://doi.org/ 10.1029/2019JB017485

Hayasaka S (1987) Geologic structure of Kagoshima Bay, South Kyushu, Japan. Assoc Geol Collab Japan 33:225-233 (in Japanese with English abstract)

Hedenquist J, Lowenstern J (1994) The role of magmas in the formation of hydrothermal ore deposits. Nature 370:519-527. https://doi.org/10.1038/ $370519 \mathrm{a} 0$

Hirose F, Nakajima J, Hasegawa A (2008) Three-dimensional seismic velocity structure and configuration of the Philippine Sea slab in southwestern Japan estimated by double-difference tomography. J Geophys Res Solid Earth. https://doi.org/10.1029/2007JB005274

Hosono T, Nakano T (2004) Pb-Sr isotopic evidence for contribution of deep crustal fluid of the Hishikari epithermal gold deposit, southwestern Japan. Earth Planet Sci Lett 222:61-69

Hosono T, Siringan F, Yamanaka T, Umezawa Y, Onodera S, Nakano T, Taniguchi M (2010) Application of multi-isotope ratios to study the source and quality of urban groundwater in Metro Manila, Philippines. Appl Geochem 25:900-909

Hosono T, Delinom R, Nakano T, Kagabu M, Shimada J (2011) Evolution model of $\delta^{34} S$ and $\delta^{18} \mathrm{O}$ in dissolved sulfate in volcanic fan aquifers from recharge to coastal zone and through the Jakarta urban area, Indonesia. Sci Total Env 409:2541-2554

Hosono T, Lorphensriand O, Onodera S, Okawa H, Nakano T, Yamanaka T, Tsujimura M, Taniguchi M (2014a) Different isotopic evolutionary trends of $\delta^{34} \mathrm{~S}$ and $\delta^{18} \mathrm{O}$ compositions of dissolved sulfate in an anaerobic deltaic aquifer system. Appl Geochem 46:30-42

Hosono T, Tokunaga T, Tsushima A, Shimada J (2014b) Combined use of $\delta^{13} \mathrm{C}$, $\delta^{15} \mathrm{~N}$, and $\delta^{34} \mathrm{~S}$ tracers to study anaerobic bacterial processes in groundwater flow systems. Water Res 54:284-296

Hosono T, Alvarez K, Lin I-T, Shimada J (2015) Nitrogen, carbon, and sulfur isotopic change during heterotrophic (Pseudomonas aerofaciens) and autotrophic (Thiobacillus denitrificans) denitrification reactions. J Contam Hydrol 183:72-81

Hosono T, Hartmann J, Louvat P, Amann T, Washington KE, West AJ, Okamura K, Böttcher ME, Gaillardet J (2018) Earthquake-induced structural deformations enhance long-term solute fluxes from active volcanic systems. Sci Rep 8:14809. https://doi.org/10.1038/s41598-018-32735-1

Hosono T, Yamada C, Shibata T, Tawara Y, Wang CY, Manga M, Rahman ATMS, Shimada J (2019) Coseismic groundwater drawdown along crustal ruptures during the 2016 Mw 7.0 Kumamoto earthquake. Water Resour Res 55:5891-5903

Hosono T, Yamada C, Manga M, Wang CY, Tanimizu M (2020) Stable isotopes show that earthquakes enhance permeability and release water from mountains. Nat Commun 11:2776. https://doi.org/10.1038/ s41467-020-16604-y

Kendall C (1998) Tracing nitrogen source and cycling in catchments. In: Kendall C, McDonnell JJ (eds) Isotope tracers in catchment hydrology. Elsevier Science B.V, The Netherland, pp 519-576

Kita I, Kai T, Ito R, Ishida M, Ueda A (2009) Magmatic fluid input to the KujuIwoyama hydrothermal system prior to the 1995 eruption of the Kuju volcano (Kyushu, Japan). Geothermics 38:294-302 
Kusakabe M, Komoda Y, Takano B, Abiko T (2000) Sulfur isotopic effects in the disproportionation reaction of sulfur dioxide in hydrothermal fluids: implications for the $\delta^{34} S$ variations of dissolved bisulfate and elemental sulfur from active crater lakes. J Volcanol Geotherm Res 97:287-307

Kusuda C, Iwamori H, Nakamura H, Kazahaya K, Morikawa N (2014) Arima hot spring waters as a deep-seated brine from subducting slab. Earth Planets Space 66:119. http://www.earth-planets-space.com/content/66/1/119

Kusuhara F, Kazahaya K, Morikawa N, Yasuhara M, Tanaka H, Takahashi M, Tosaki Y (2020) Original composition and formation process of slab-derived deep brine from Kashio mineral spring in central Japan. Earth Planets Space 72:107. https://doi.org/10.1186/s40623-020-01225-y

Luccio FD, Chiodini G, Caliro S, Cardellini C, Convertito V, Pino NA, Tolomei C, Ventura G (2018) Seismic signature of active intrusions in mountain chains. Sci Adv 4:e1701825. https://doi.org/10.1126/sciadv.1701825

Matsumoto Y (1979) Some problems on volcanic activities and depression structures in Kyushu, Japan. Memoir Geol Soc Japan 16:127-139 (in Japanese with English abstract)

Moreno T, Wallis S, Kojima T, Gibbons W (2016) The geology of Japan. Geological Society, London

Morikawa N, Kazahaya K, Takahashi M, Inamura A, Takahashi HA, Yasuhara M, Ohwada M, Sato T, Nakama A, Handa H, Sumino H, Nagao K (2016) Widespread distribution of ascending fluids transporting mantle helium in the fore-arc region and their upwelling processes: Noble gas and major element composition of deep groundwater in the Kii Peninsula, southwest Japan. Geochim Cosmochim Acta 182:173-196

Nakada S, Yakamoto T, Maeno F (2016) Miocene-Holocene volcanism. In: Moreno T, Wallis S, Kojima T, Gibbons W (eds) The geology of Japan. Geological Society, London, pp 237-308

Nakajima J, Hasegawa A (2007) Subduction of the Philippine Sea plate beneath southwestern Japan: slab geometry and its relationship to arc magmatism. J Geophys Res Solid Earth. https://doi.org/10.1029/2006J B004770

Nakamura H, Iwamori H, Nakagawa M, Shibata T, Kimura Jl, Miyazaki T, Chang Q, Vaglarov BS, Takahashi T, Hirahara Y (2019) Geochemical mapping of slab-derived fluid and source mantle along Japan arcs. Gondwana Res 70:36-49

Ohsawa S, Kazahaya K, Yasuhara M, Kono T, Kitaoka K, Yusa Y, Yamaguchi K (2002) Escape of volcanic gas into shallow groundwater systems at Unzen Volcano (Japan): evidence from chemical and stable carbon isotope compositions of dissolved inorganic carbon. Limnology 3:169-173

Ohsawa S, Sakai T, Yamada M, Mishima T, Yoshikawa S, Kagiyama T (2011) Dissolved inorganic carbon extremely rich in mantle component of hot spring waters from the Hitoyoshi Basin located in a non-volcanic region of central Kyushu, Japan. J Hot Spring Sci 60:410-417

Okumura A, Hosono T, Boateng D, Shimada J (2018) Evaluations of the downward velocity of soil water movement in the unsaturated zone in a groundwater recharge area using $\delta 180$ tracer: the Kumamoto region, southern Japan. Geol Croat 71:2. https://doi.org/10.4154/gc.2018.09

Perez-Fodich A, Derry LA (2019) Organic acids and high soil $\mathrm{CO}_{2}$ drive intense chemical weathering of Hawaiian basalts: Insights from reactive transport models. Geochim Cosmochim Acta 249:173-198

Rees CE, Jenkins WJ, Monster J (1978) The sulfur isotopic composition of ocean water sulphate Geochim Cosmochim Acta 42·377-381

Rive K, Gaillardet J, Agrinier P, Rad S (2013) Carbon isotopes in the rivers from the Lesser Antilles: origin of the carbonic acid consumed by weathering reactions in the Lesser Antilles. Earth Surf Proc Land 38:1020-1035
Sakai T, Ohsawa S, Yamada M, Mishima T, Yoshikawa S, Kagiyama T, Oue K (2011) Origin of dissolved inorganic carbon of hot spring waters discharged from the non-volcanic region of central Kyusyu, Japan. J Hot Spring Sci 60:418-443

Sano Y, Marty B (1994) Origin of carbon in fumarolic gas from island arcs. Chem Geol 119:265-274

Schoeller H (1977) Geochemistry of groundwater. An international guide for research and practice. UNESCO 15:1-18

Strebel O, Böttcher J, Fritz P (1990) Use of isotope fractionation of sulfate-sulfur and sulfate-oxygen to assess bacterial desulfurication in a sandy aquifer. $J$ Hydrol 121:155-172

Takashima C, Kano A (2005) Depositional processes of travertine developed at Shionoha hot spring, Nara Prefecture, Japan. J Geol Soc Japan 111:751-764

Taylor BE, Wheeler MC, Nordstrom DK (1984) Stable isotope geochemistry of acid mine drainage: experimental oxidation of pyrite. Geochim Cosmochim Acta 48:2669-2678

Togo Y, Kazahaya K, Tosaki Y, Morikawa N, Matsuzaki H, Takahashi M, Sato T (2014) Groundwater, possibly originated from subducted sediments, in Joban and Hamadori areas, southern Tohoku, Japan. Earth Planets Space 66:131. http://www.earth-planets-space.com/content/66/1/131

Tomaru H, Ohsawa S, Amita K, Lu Z, Fehn U (2007) Influence of subduction zone settings on the origin of forearc fluids: Halogen concentrations and ${ }^{129} \mathrm{I} / \mathrm{I}$ ratios in waters from Kyushu, Japan. Appl Geochem 22:676-691

Tuttle MLW, Breit GN, Cozzarelli IM (2009) Processes affecting $\delta^{34} S$ and $\delta^{18} \mathrm{O}$ values of dissolved sulfate in alluvium along the Canadian River, central Oklahoma, USA. Chem Geol 265:455-467

Ueda A, Sakai H (1984) Sulfur isotope study of Quaternary volcanic-rocks from the Japanese Islands Arc. Geochim Cosmochim Acta 48:1837-1848

van Everdingen RO, Krouse HR (1985) Isotope composition of sulphates generated by bacterial and abiological oxidation. Nature 315:395-396

Yamada M, Ohsawa S, Kazahaya K, Yasuhara M, Takahashi H, Amita K, Mawatari $\mathrm{H}$, Yoshikawa S (2011) Mixing of magmatic $\mathrm{CO}_{2}$ into volcano groundwater flow at Aso volcano assessed combining carbon and water stable isotopes. J Geochem Explor 108:81-87

Yokose H, Yanashima T, Kikuchi W, Sugiyama N, Shinohara A, Takeuchi T, Nagao K, Kodama K (2009) Episodic magmatism since 5Ma in the western part of Beppu-Shimabara graben, Kyusyu, Japan. J Mineral Petrol Econ Geol 94:338-348 (in Japanese with English abstract)

Yoshida K, Hirajima T, Ohsawa S, Kobayashi T, Mishima T, Sengen Y (2015) Geochemical features and relative $\mathrm{B}-\mathrm{Li}-\mathrm{Cl}$ compositions of deep-origin fluids trapped in high-pressure metamorphic rocks. Lithos 226:50-64

Zhao D, Yamashita K, Toyokuni G (2018) Tomography of the 2016 Kumamoto earthquake area and the Beppu-Shimabara graben. Sci Rep 8:15488. https://doi.org/10.1038/s41598-018-33805-0

Zhao D, Wang J, Huang Z, Liu X (2021) Seismic structure and subduction dynamics of the western Japan arc. Tectonophysics 802:228743. https:// doi.org/10.1016/j.tecto.2021.228743

\section{Publisher's Note}

Springer Nature remains neutral with regard to jurisdictional claims in published maps and institutional affiliations. 